\title{
Population genetics of human glyoxalases
}

\author{
PAUL J. THORNALLEY \\ Department of Chemistry and Biological Chemistry, University of Essex, Wivenhoe Park, Colchester CO4 3SQ, UK
}

\begin{abstract}
The gene for glyoxalase I (E.C. 4.4.1.5), Glo, has two alleles, $G l o^{1}$ and $G l o^{2}$, which are autosomally inherited in a co-dominant manner. $G l^{I}$ allele-frequency is highest in native Alaskan-Eskimo and Indian populations and decreases geographically south and east, to minimum levels in AboriginalAustralian populations and native tribes in Papua New Guinea. There was no correlation between $G l{ }^{l}$ frequency and incidence of insulin-dependent diabetes mellitus (IDDM). The frequencies of GLO phenotypes, Glo 1-1, Glo 1-2 and Glo 2-2, are disturbed in IDDM and there is a suggestion that IDDM patients with or without chronic, clinical complications have characteristic phenotype frequencies.
\end{abstract}

Keywords: diabetes, diabetic complications, glyoxalase.

\section{Introduction}

The glyoxalase system catalyses the conversion of methylglyoxal tò D-lactic acid, via the intermediate S-Dlactoylglutathione (Racker, 1951). There are two constituent enzymes: glyoxalase I (E.C. 4.4.1.5), a dimeric protein which catalyses the formation of S-D-lactoylglutathione from methylglyoxal and reduced glutathione

\section{$\mathrm{MeCOCHO}+\mathrm{GSH} \stackrel{\text { Glyoxalase I }}{\longrightarrow} \mathrm{MeCH}(\mathrm{OH}) \mathrm{CO}-\mathrm{SG}$}

and glyoxalase II (E.C. 3.1.2.6), a monomeric protein that catalyses the hydrolysis of S-D-lactoylglutathione to $\mathrm{D}$-lactate, regenerating reduced glutathione

$$
\begin{gathered}
\mathrm{MeCH}(\mathrm{OH}) \mathrm{CO}-\mathrm{SG}+\mathrm{H}_{2} \mathrm{O} \stackrel{\text { Glyoxalase II }}{\longrightarrow} \\
\mathrm{MeCH}(\mathrm{OH}) \mathrm{CO}_{2} \mathrm{H}+\mathrm{GSH}
\end{gathered}
$$

Recent investigations of the glyoxalase system have suggested that there may be characteristic activities of glyoxalase enzymes associated with the development of clinical complications in insulin-dependent diabetes mellitus (Thornalley et al., 1989), and glyoxalase activity may be a predisposition factor for developing complications should an individual develop the disease (Thornalley, 1990). The genetics and polymorphism of glyoxalase have also been investigated in diabetes mellitus and associated clinical complications. There is considerable variation in the population genetics of glyoxalase with geographical location. This provides an opportunity to investigate the correlation of glyoxalase allele and phenotype frequencies with the incidence of diabetes mellitus and its susceptibility to complications.
This report describes the genetic characteristics of glyoxalase I and II, surveys the variation of allele frequency with geographical location and assesses the association of glyoxalase with the incidence of diabetes mellitus and associated complications.

\section{Genetics of glyoxalase I}

Human glyoxalase I was found to exhibit genetic polymorpism originally in red blood-cells (Kompf et al., 1975a). There were three phenotypes Glo 1-1, Glo 1-2 and Glo 2-2, representing the homozygous and heterozygous expression of a two allelic gene, $G l o^{1}$ and $G^{2}{ }^{2}$ (Kompf et al., 1975b). An analogous phenotypic expression was found in 23 different human tissues in each of 49 autopsies (Stohlmacher \& Haferland, 1980). The Glo alleles are inherited autosomally in a codominant manner. The Glo locus has been assigned to chromosome 6 by somatic-cell hybridization (Bender \& Grzeschik, 1976), and to the major histocompatibility complex by linkage analysis (Kompf et al., 1976). Glo lies between the centromere and HLA-DR; the meiotic distance between HLA-DR is $\sim 6 \mathrm{cM}$ (Bakker et al., 1979; Leach et al., 1986).

The allele frequencies of Glo in geographically classified human-populations are presented in Fig. 1. The $G l o^{1}$ allele-frequency is highest in native tribes in Alaska (Inpiat, Aleuts, Tlingits, Yupik and Athabaskan), 0.6663-0.8529, and is lowest in the Aboriginal population of Australia, 0-0.1008, Papua New Guinea, 0-0.1558 and island of the Western Pacific-E. Carolines, 0.0455 (Fig. 1). 


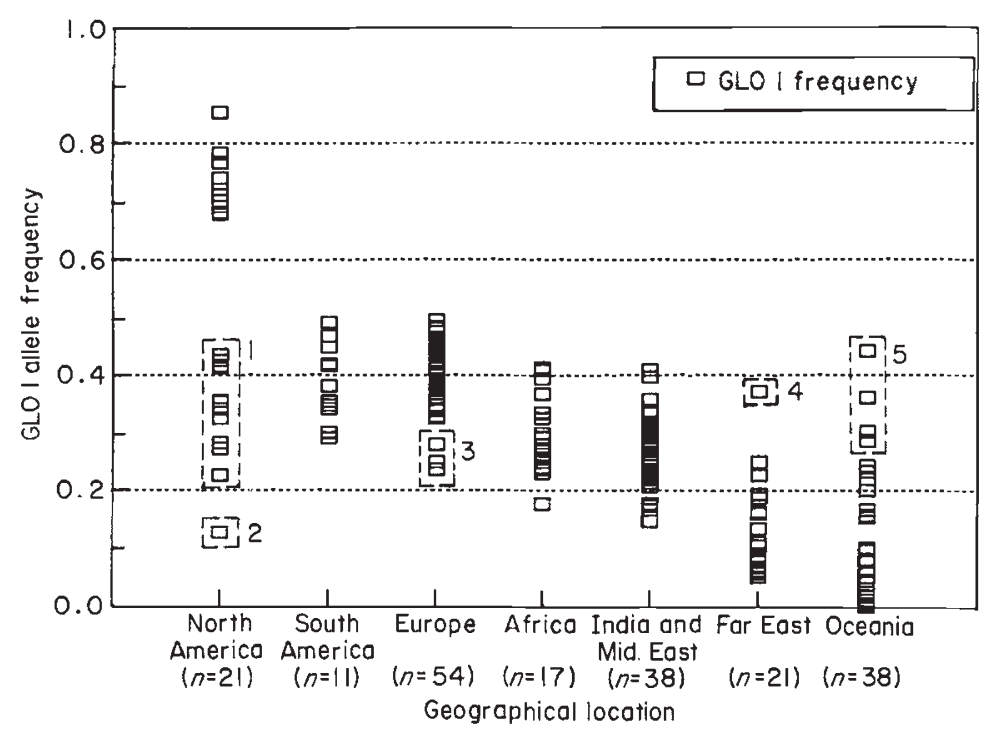

Fig. 1 Variation in $\mathrm{Glo}^{\prime}$ allele-frequency with geographic location. Data taken from 202 reports (16 other reports rejected for failure of the Hardy-Weinberg Principle). A full list of data and references is avilable on request. Data are shown in subcontinental classification. Where immigrant populations with $G l o^{\prime}$ allele-frequencies significantly different from the native population were defined, the immigrant class is identified:

(1) European and African immigrants in USA;

(2) Native Dogrib tribe (Canada, NW Territories);

(3) Indian and African immigrants in UK;

(4) European immigrants in Siberia;

(5) European and Indian immigrants in Australia, Tokelau and Malaya.
The $G l o^{I}$ allele-frequency decreases geographically south and east from Alaska, to Europe or South America, through Africa, the Middle East and India, to the very low $G l o^{l}$ allele-frequencies of the Far East (Japan and China) and Oceania (Australian Aboriginals, Papua New Guinea). Where there is extreme diversity of $G l o^{l}$ allele-frequency within a region, this can be assigned to an immigrant populationEuropeans and Africans in the USA (North America), Indians and Africans in the United Kingdom (Europe), European immigrants in Eastern Siberia (Far East), Australia and other Pacific island (Oceania). One exception to this trend was the report for the native Dogrib tribe, Northwest Territories of Canada which gave an anomalously low $G l o^{l}$ allele-frequency (0.1266).

Glyoxalase I is not polymorphic in closely-related hominoid species, e.g. Pan troglodytes - the chimpanzee (Payne et al., 1982). The electrophoretic mobility of glyoxalase I in the chimpanzee was found to be identical to the human Glo 2-2 phenotype. The $G l o^{2}$ allele has been proposed to be the ancestral allele with the $G l o^{J}$ allele arising by mutation. The geographical distribution of $\mathrm{Glo}^{J}$ allele-frequency is consistent with this mutation occurring in North America or there being some environmental advantage for the $G l o^{J}$ allele in North American and West European population.

\section{Polymorphism of glyoxalase / in diabetes mellitus}

Polymorphism of glyoxalase I has been described in five independent surveys of diabetic patients and normal, healthy controls. There was no significant difference in $G l o^{J}$ allele-frequency between these two groups. The distribution, however, of GLO phenotypes was disturbed.

For insulin-dependent diabetes mellitus (IDDM) there was a significant disturbance in GLO phenotype distribution: an increase in Glo 1-1 homozygote (McCann et al., 1981; Cambdon de Mouzon et al., 1982) or an increase in Glo 1-2 heterozygote (Kirk et al., 1985). Other surveys (Allannic et al., 1985; Kirk et al., 1979) found no significant difference between IDDM patients and controls. The present paper reports an investigation of the relationship between geographical variation in glyoxalase I genotype and the incidence of IDDM for 10 countries, using the recently collated data of LaPorte et al. (1985), and the corresponding $G l o^{J}$-genotype data obeying the Hardy-Weinberg principle. No significant correlation was found using the Kendall Rank-correlationcoefficient analysis between the incidence of IDDM and $G l o^{1}$ allele-frequency or $G l o$-genotype distribution $(Z=0.447$, Fig. 2$)$.

For non-insulin-dependent diabetes mellitus (NIDDM), a disturbance in the GLO-phenotype distribution has also been reported (Kirk et al., 1979), associated with an increase in the Glo 2-2 phenotype, but this was not confirmed (Kirk et al., 1985; McCann et al., 1981).

Diabetic patients suffer chronic complications (retinopathy, cataract, peripheral neuropathy, nephropathy and generalized microangiopathy). No genetic link with the development of complications has yet been established. There has only been one survey relating the development of retinopathy and neuropathy to GLO phenotypes. Here, IDDM patients without complications (retinopathy, neuropathy) had a significant excess of the homozygote Glo 1-1 compared to 


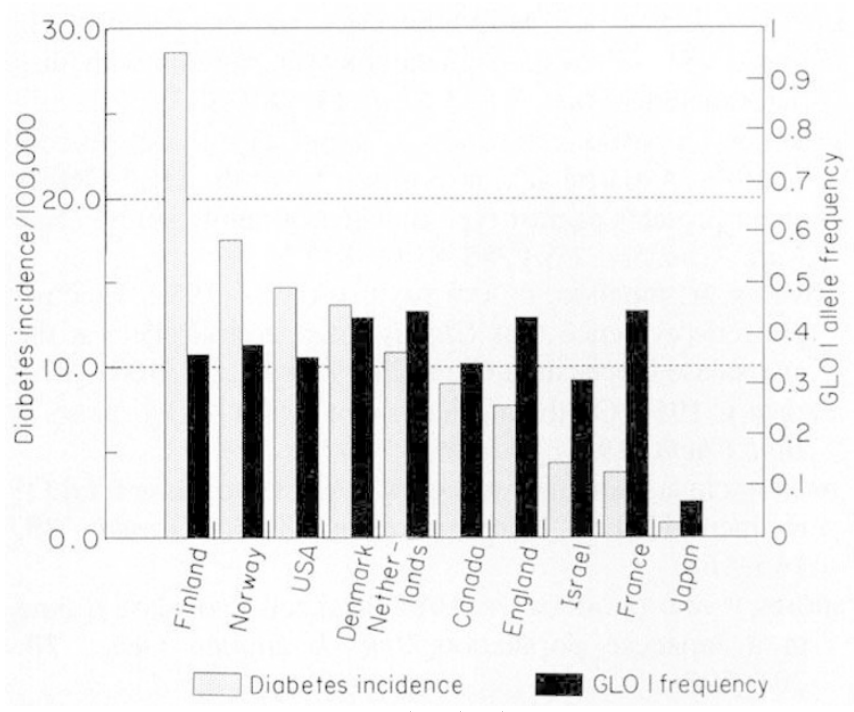

Fig. 2 Geographical population incidence of insulindependent diabetes mellitus (IDDM) and $\mathrm{Glo}^{\prime}$ allelefrequency. IDDM incidence was taken from LaPorte et al. (1985). Glo' frequency was calculated from reports of similar ethnic composition to the diabetes incidence data

normal healthy controls (McCann et al., 1981). It was also in IDDM patients that characteristic activities of red-blood-cell glyoxalases were found for patients with or without complications (Thornalley et al., 1989).

International comparisons of $G l o^{1}$ allele-frequency and susceptibility to complications are made with caution since the diagnosis and clinical management may vary. Cumulative survival-rates for IDDM patients may give an indication of the severity of complications. Data are available for Finland, USA, Israel and Japan - countries with well developed primary health care services. Survival rates are very similar for Finland, USA and Israel (0.956-0.967) but very much lower in Japan (0.898) (LaPorte, 1990). It is of interest that the $G l o^{I}$ frequencies for Finland (0.358), USA (0.379) and Israel $(0.306)$ are also similar, whereas $G l o^{l}$ frequency in Japan is very much lower (0.067). Hence, a deficiency in $G l o^{I}$ allele may be associated with the occurrence of diabetic complications and high mortality.

\section{Genetics of glyoxalase II}

The gene for glyoxalase II humans (HAGH) is on chromosome 16 (Honey \& Shows, 1981). There is usually only one phenotype expressed, although a rare second form (frequency 0.016 ) was found in a Micronesian population (Board, 1980; Sugita \& Takahama, 1983). Glyoxalase-II polymorphism occurs in other species. A survey of 10 anthropoid primates indicated a high degree of polymorphism of erythrocyte glyoxalase II (Board et al., 1981). The disturbance of glyoxalase II phenotypes in diabetes has not yet been investigated. of glyoxalase II phenotypes in diabetes has not yet been investigated.

\section{Relevance of glyoxalase genetics to diabetes}

Genetic susceptibility markers for IDDM have been suggested (Todd et al., 1987; Morel et al., 1988). The nature of the genetic contribution to the aetiology of NIDDM remains obscure (Jarrett, 1989). There was no correlation between the incidence of IDDM and glyoxalase I allele-frequency, and disturbances in glyoxalase I phenotypes in IDDM and NIDDM have not been generally confirmed. There is a suggestion, however, that IDDM patients with or without chronic clinical complications have characteristic phenotypefrequencies (McCann et al., 1981) and glyoxalase activities (Thornalley et al., 1989). The implication of an involvement of glyoxalases in the development of complications is a novel approach (Thornalley, 1990) and genetic aspects of this require further investigation.

\section{Acknowledgements}

I would like to thank the Wellcome Trust and ICI Pharmaceuticals for their interest in and support for this research. This is a contribution from the Glyoxalase Research Group at the University of Essex.

\section{References}

aLlanNiC, H., FaUCheT, R., GUEGUen, M., PHENG SAVATJ, H., Dinh KNOI, T. AND GENETET, B. 1985. Factor B $\left(B_{f}\right)$ and glyoxalase genes in insulin-dependent diabetes mellitus. Diab. Metab., 11, 22-26.

BAKKER, E., PEARSON, P., MEERA KAHN, P., SCHREUdER, G. AND MADAM, K. 1979. Orientation of major histocompatibility (MHC) genes relative to the centromere of human chromosome 6. Clin. Genet., 15, 198-202.

BENDER, K. AND GRESCHIK, K. H. 1976. Assignment of the genes for human glyoxalase I to chromosome 6 and for human esterase D to chromosome 13. Cytogenet. Cell. Genet., 16, 93-96.

BOARD, P. G. 1980. Genetic polymorphism of human erythrocyte glyoxalase II. Am. J. Hum. Genet., 32, 690-694.

BOARD, P. G., GIBBS, C. J. JR AND GAJDUSEX, D. C. 1981. Polymorphism of erythrocyte glyoxalase II in anthropoid primates. Folia Primatol., 36, 138-143.

CAMBON-DE MOUZON, A., OHAYON, E., HAUPTMANN, G., SEVIN, A., ABBAL, M., SOMMER, E., VERGNES, H. AND DUCOS, J. 1982. HLAA, B, C, DR antigens, $B_{f}, C 4$ and glyoxalase I (GLO) polymorphisms in French Basques with insulin-dependent diabetes mellitus. Tissue Antigens, 19, 366-379.

HONEY, N. K. AND SHOWs, T. B. 1981. Assignment of the glyoxalase II gene (HAGH) to human chromosome 16. Hum. Genet., 58, 358-361.

JARRETT, R.J. (1989). Epidemiology and public health aspects of non-insulin-dependent diabetes mellitus. Epidemiol. Revs, 11, 151-171.

KIRK, R. L., RANFORD, P. R., SERJEANTSON, S. W., THOMPSON, A. R., 
MURIRATHNAM-CHETTY, S. M., JOHN, L., MOHAN, V., RAMACHANDRAN, A., SNEHOLATHA, C. AND VISNANATHAN, M. 1985. HLA, complement C2, C4, properdin factor B and glyoxalase types in South Indian diabetics. Diab. Res. Clin. Pract., 1, 41-47.

KIRK, R. L., THEOPHILUS, J., WHITEHOUSE, S. COURT,

1979. Genetic susceptibility to diabetes mellitus: the distribution of properdin factor B and glyoxalase (GLO) phenotypes. Diabetes, 28, 949-951.

KOMPF, J., BISSBORT, S., GUSSMANN, S. AND RITTER, H. 1975a. Polymorphism of red glyoxalase I (EC 4.4.1.5). A new genetic marker. Humangenetik, 27, 141-143.

KOMPF, J., BISSBORT, S. AND RITTER, H. 1975b. Red cell glyoxalase I (EC 4.4.1.5): formal genetics and linkage relations. Humangenetik, 28, 249-251.

KOMPF, J., BISSBORT, S. A AND SCHUNTER, F. 1976. Confirmation of linkage between the loci of HLA and glyoxalase I. Humangenetik, 32, 197-198.

LAPORTE, R. E. 1991. Mortality and insulin-dependent diabetes mellitus: an international evalution. Diabetes (in press).

LAPORTE, R. E., TAJIMA, N., AKERBLOM, H. K., BERLIN, N., BROSSEAU, J., CHRISTY, M., DRASH, A. L., FISHBEIN, H., GREEN, A., HAMMAN, R., HARRIS, M., KING, H., LARON, Z. AND NEIL, A. 1985. Geographic differences in the risk of insulin-dependent diabetes mellitus: the importance of registries. Diabetes Care, 8 , (Suppl. 1) 101-107.

LEACH, R., DEMARS, R., HASSTEDT, S. AND WHITE, R. 1986. Construction of a map of the short arm of human chromosome 6. Proc. Natl. Acad. Sci. USA , 83, 3909-3913.
MCCANN, V. J., DAVIS, R. E., WELBOURN, T. A., CONSTABLE J. AND BEALE, D. G. 1981. Glyoxalase phenotypes in patients with diabetes mellitus. Aust. N.Z. J. Med., 11, 380-382.

MOREL, P. A., DORMAN, J. S., TODD, J. A., MCDEVITT, H. O. AND TRUCCO, - 1 nח Aspartic acid at position 57 of the HLA-DQ $\beta$ tects against type diabetes: a family study. Proc. Natl. Acad. Sci., USA, 85, 8111-8115.

PAYNE, R. H., GRENNIG, C. AND DAVIDSON, w. S. 1982. Electrophoretic evidence that $G l o^{2}$ is the ancestral allele at the glyoxalase I locus in humans. Hum. Hered., 32, 404-407.

RACKER, E. 1951. On the mechanism of action of glyoxalase. $J$. Biol. Chem., 190, 685-696.

STOHLMACHER, P. AND HAFERLAND, w. 1980. Glyoxalase I (GLO) in menschlichen Körpergeweben. Z. Rechtsmed., 85, 165-168.

SUGITA, H. AND TAKAHAMA, K. 1983. Red cell glyoxalase II type in a Japanese population. Jpn. J. Human Genet. 28, 201-203.

THORNALLEY, P. J. 1990. The glyoxalase system: new developments towards functional characterisation of a metabolic pathway fundamental to biological life. Biochem. J., 269 , $1-11$.

THORNALLEY, P. J., HOOPER, N. I., FLORKOWSKI, C., JONES, A. P., LUNEC, J. AND BARNETT, A. H. 1989. The human red blood cell glyoxalase system in diabetes mellitus. Diabetes Res. Clin. Pract. 7, 115-120.

TODD, J. A., BELL, J. J. AND McDEVITT, H. O. 1987. HLA-DQ gene contributes to susceptibility and resistance to insulindependent diabetes mellitus. Nature, 329, 599-604. 